\title{
Effects of early protein malnutrition on learning in the rat
}

\author{
N. R. REMLEY, D. R. ARMSTRONG, D. P. GILMAN, \\ and L. F. MERCER, JR. \\ Texas Christian University, Fort Worth, Texas 76129
}

\begin{abstract}
Animals were reared on a diet of commercially available corn grits from weaning to approximately 120 days of age. Littermate controls were fed Purina Laboratory Chow. The subjects' learning ability was tested in a two-way active avoidance task and a black-white visual discrimination task. The grits-fed animals did not develop physically and remained as small as weanling rats throughout the study. The data from the learning tasks indicate that there were no differences in learning ability between the protein-malnourished animals and the normal littermates.
\end{abstract}

It has been generally assumed that low-protein diets during development can result in reduced mental functioning (Cravioto, DeLicardie, \& Birch, 1966; Cravioto \& Robles, 1965; Kaplan, 1972; Winick, 1976). In the last few years, however, a variety of studies using nonhuman animals as subjects have been reported that raise serious doubts about the validity of this assumption. For example, in an elegant series of studies, Zimmerman, Geist, and Strobel (1975) compared the performance of developing malnourished monkeys and control animals on a variety of learning tasks. They reported that there were no differences on delayed response, learning set, object discrimination, object quality discrimination, or simple reversal learning tasks. The animals reared on the low-protein diet, however, did not perform as well as the control subjects on conditional discrimination, embedded-figures, and cross-string tasks. Zimmerman et al. concluded that the deficits found were not the result of reduced cognitive abilities, but rather the functions of attentional or emotional factors.

Most of the protein-malnutrition studies using nonhumans as subjects usually report using a low-protein but otherwise nutritionally adequate diet. One can assume, however, that diets of the human subjects used in the field studies probably were not only low in protein but were also very poor in other nutritional aspects. For example, Dent and Caster (1971) reported that low-income groups in the rural southern United States obtain much of their dietary protein from corn grits and cheap cuts of meat. It would seem worthwhile, therefore, to explore the possible effects of not only a lowprotein diet, but also a poor protein diet on the learning ability of animals. The purpose of this paper is to report the effects of such a diet on performance of rats in both an avoidance learning task and an appetitive discrimination task.

Instead of manufacturing an experimental diet, we felt that it might be more meaningful to use a diet that would be more comparable to the diets found in those countries in which cognitive deficits have been found to be correlated with diet. The most common sources of proteins for many people are the grains and cereals. We therefore wanted to use a cereal or grain-based diet. Parthemos (1974) reported that a diet consisting solely of commercially available corn grits produces all the physical retardation effects of the more elaborate lowprotein diets used in most studies. Furthermore, corn grits are low in protein and contain none of the amino acids lysine and tryptophan. Corn grits also contain an excess of the amino acid leucine.

\section{EXPERIMENT 1: ACTIVE AVOIDANCE}

\section{Method}

Subjects. The subjects were 12 male and 12 female albino rats from six litters of Sprague-Dawley dams. At the time of weaning, two groups ( $n=6$ males, $n=6$ females) were placed on an exclusive diet of corn grits (Quaker Instant Grits), and two groups of littermate controls ( $n=6$ males, $n=6$ females) were maintained on a diet of Purina Laboratory Chow. The precooked variety of grits was used to avoid the additional nutritional problems of a diet of raw starch (Dent \& Caster, 1971). The pups were housed individually from the time of weaning onward and were maintained on a 12-h light-dark cycle.

Apparatus. Two automated shuttleboxes (LTV Model 146-04) were used to test for two-way active avoidance learning. The associated electromechanical programming and recording equipment was maintained in an adjacent room.

Procedure. At 30 days of age, half of the animals were placed on the grits diet and half of the animals were placed on the normal diet. Water was available on an ad-lib schedule for all animals. All animals were maintained on the diets throughout the study. Testing for two-way active avoidance learning was begun when the subjects reached 90 days of age.

An animal was placed in the testing chamber, and after $1.0 \mathrm{~min}$, a tone and light came on. If the animal had not made an avoidance response before the end of a $10-\mathrm{sec}$ interval, the grid floor was electrified with a current of $1.0 \mathrm{~mA}$. When the animal made an escape response, both the CS and the UCS were terminated. If the animal responded during the 10 -sec CS interval, the CS was terminated and an avoidance response was recorded. Each trial was separated by a 1.0 -min ITI. Each subject was given 10 trials/day for 15 days. 


\section{Results}

While the subjects maintained on the normal diet showed normal increases in body weight, the animals maintained on the grits diet increased their body weights only minimally. These data are illustrated in Table 1 .

The grits-fed rats were mobile and appeared to be normally responsive to environmental stimuli. Physically, the grits-fed rats appeared to be in good health, and at no time throughout the study did the grits-fed subjects show any signs of malnutrition or developing kwashiorkor.

The results from the avoidance task indicate that the grits-fed rats were able to learn the two-way active avoidance task just as readily as the littermate controls. A three-way analysis of variance of the percentage of correct responses per day revealed no significant differences as a function of diet or sex. There was a significant days effect $[F(14,280)=19.6]$, but there were no significant interactions. Since there was no significant sex effect, the data for the two sexes were pooled and these data are illustrated in Figure 1.

\section{EXPERIMENT 2: VISUAL DISCRIMINATION LEARNING}

\section{Method}

Subjects. The subjects were eight male and eight female albino rats from three litters of Sprague-Dawley dams. The pups were housed individually from the time of weaning and were maintained on a 12 -h light-dark cycle.

Apparatus. The black-white discrimination apparatus had two pairs of alleys. The two outside alleys were painted black, and the two inside alleys were painted white. Each alley measured $100 \times 12 \times 12 \mathrm{~cm}$ high. The startbox was painted gray and measured $45 \times 12 \times 12 \mathrm{~cm}$ high and had a guillotine door at the exit. The apparatus was constructed so that the startbox could be placed at the entrance of either pair of alleys, thereby alternating the position of the black and white alleys. The area between the startbox exit and the choice point of each pair of alleys measured $25 \mathrm{~cm}$ long, $12 \mathrm{~cm}$ high, and $12 \mathrm{~cm}$ wide at the startbox and $24 \mathrm{~cm}$ wide at the choice point. Guillotine doors were placed at each goalbox to prevent retracing. One small watch glass was placed at the end of each alley. In the correct alley, the watch glass held $2 \mathrm{ml}$ of an $8 \%$ sucrose solution.

Procedure. At the time of weaning, the subjects were divided into two groups with equal representation of litters. One group $(n=4$ males and 4 females) was placed on a diet of corn grits. The other group ( $n=4$ males and 4 females) was maintained on a normal diet of Purina Laboratory Chow.

At 120 days of age, the subjects were tested in the discrimination task. All animals were deprived of water prior to the daily test sessions. The smaller grits-fed animals were deprived for

Table 1

Mean Body Weights (in Grams) as a Function of Diet

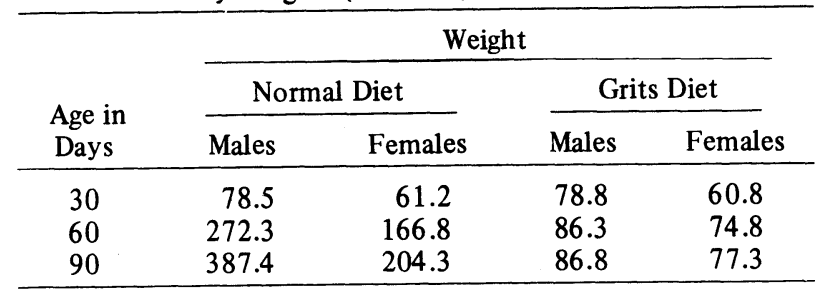

Note $-N=6$ males and 6 females in both conditions.

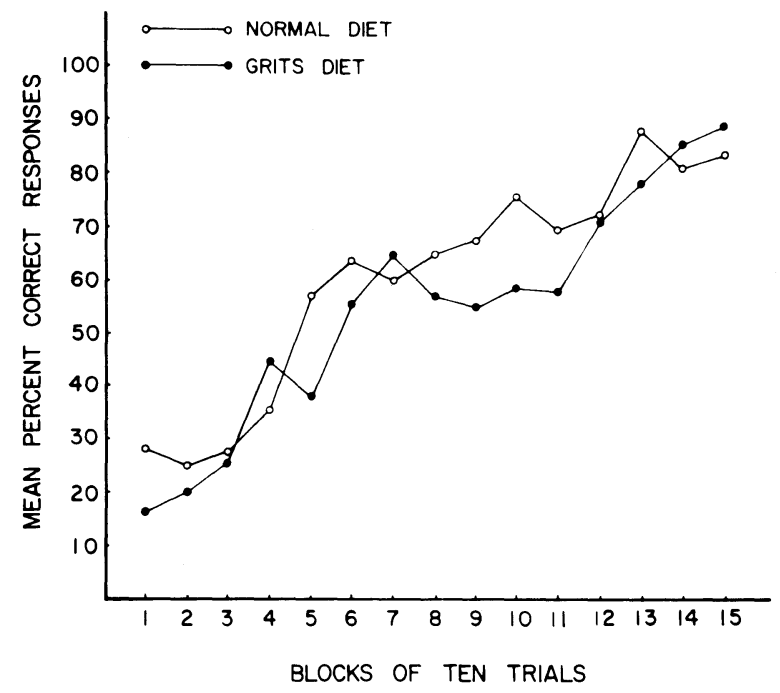

Figure 1. Active two-way avoidance: mean percent correct responses for blocks of 10 trials.

$4.5 \mathrm{~h}$, and the larger littermates were deprived for $7.0 \mathrm{~h}$. Trials were conducted for 12 days at 10 trials/day with an ITI of $30 \mathrm{sec}$. Position of the correct alley was determined by using the Gellerman (1933) series to prevent the development of position habits.

At the beginning of a trial, the subject was placed in the startbox for a minimum of $30 \mathrm{sec}$. The startbox door was opened only after the subject had oriented toward the door. If no exit occurred within $60 \mathrm{sec}$, the trial was recorded as "no response." Upon leaving the startbox, the subject was given $2.0 \mathrm{~min}$ to enter one of the two alleys. Failure to enter an alley in $2.0 \mathrm{~min}$ ended the trial, and a "no response" was recorded. After the subject entered the correct goalbox, the door was lowered and the subject was allowed to drink the $8 \%$ sucrose solution for $15 \mathrm{sec}$. If the subject entered the incorrect goalbox, the door was lowered and the subject was confined in the goalbox for $30 \mathrm{sec}$.

\section{Results}

As was the case in the first study, the animals maintained on the grits diet did not physically develop as readily as did their littermates. These growth data are illustrated in Table 2. The grits-fed animals appeared to be in good physical health, except they were greatly retarded in physical size.

The data from the discrimination task indicated that the subjects fed the grits diet were superior to their littermates in learning the black-white discrimination. The grits-fed rats achieved a $93 \%$ correct performance

Table 2

Mean Body Weights (in Grams) as a Function of Diet

\begin{tabular}{cccccc}
\hline & \multicolumn{4}{c}{ Weight } \\
\cline { 2 - 3 } Age in & \multicolumn{2}{c}{ Normal Diet } & & \multicolumn{2}{c}{ Grits Diet } \\
\cline { 2 - 3 } \cline { 5 - 6 } Days & Males & Females & & Males & Females \\
\hline 35 & 125.7 & 109.8 & & 113.2 & 98.5 \\
66 & 278.5 & 196.8 & & 114.5 & 110.2 \\
95 & 389.0 & 244.0 & & 118.2 & 116.8 \\
\hline
\end{tabular}

Note $-N=4$ males and 4 females in both conditions. 


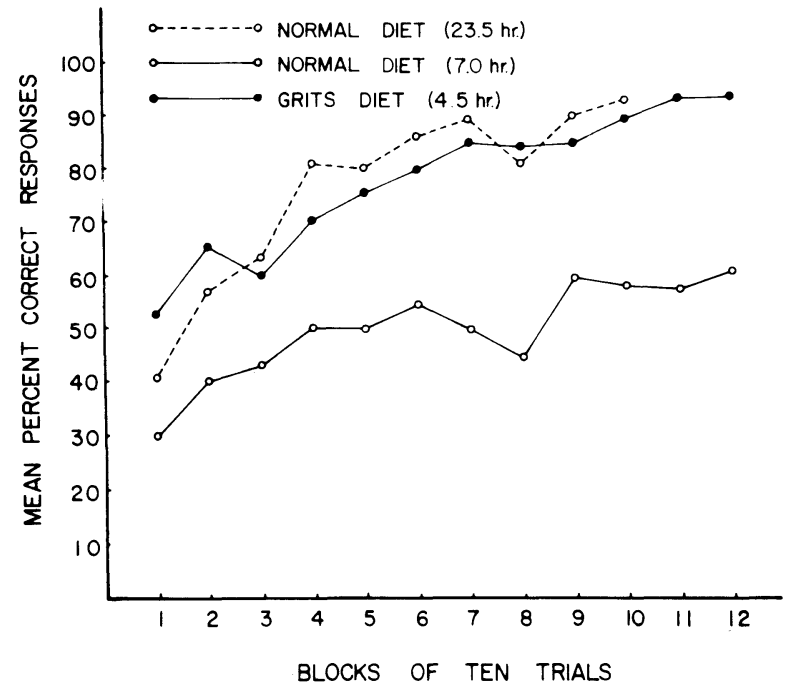

Figure 2. Black-white visual discrimination: mean percent correct responses for blocks of 10 trials.

on Days 11 and 12 of testing. The controls achieved only a $54 \%$ correct performance at this time $(p=.006)$. These data are illustrated in Figure 2. Further examination of the data indicated that the control subjects had more "no-response" scores than did the grits-fed animals. This suggested the possibility that the differences between the two groups was the result of motivational differences, rather than differences in learning ability. To test this hypothesis, a third group of animals maintained on a normal diet was tested in the apparatus for 10 days at 10 trials/day. These subjects were maintained on a 23.5-h water-deprivation schedule. The data from these subjects are also illustrated in Figure 2. Since these animals were not littermates and were run in the task at a different time, no statistical comparisons were made. As can be seen in Figure 2, however, there appears to be no difference between the performance of the smaller grits-fed subjects and the normal subjects maintained on a 23.5-h water-deprivation schedule.

\section{DISCUSSION}

Although a poor protein diet produces dramatic retardation of physical development, the data reported here do not support the conclusion that a poor protein diet early in life will necessarily result in mental retardation. In both the avoidance learning task and the visual discrimination task with "appetitive reinforcement, the animals maintained on the poor protein diet were able to perform as well as the normal controls.

The fact that the grits diet is deficient in the amino acid tryptophan suggests that brain serotonin levels do not have major effects on learning ability. Fernstrom and Lytle (1976) have reported that brain tryptophan levels decrease by $60 \%$ and brain serotonin levels by $28 \%$ in animals maintained on a cornbased diet. Likewise, Fernstrom and Hirsch (1977) report that the rate of serotonin synthesis in the brain is reduced in corn-fed rats and that this effect is correlated with the amount of tryptophan in the diet.

Segall and Timeras (1976) have suggested that the serotonin depletion resulting from diets such as corn grits is responsible for the arrested physical growth.

One possible explanation for why the protein-poor diets have major physical but only minor behavioral effects is provided by Forbes, Tracy, Resnick, and Morgane (1977). They reported that, although protein-malnourished rats show retarded development of body weight, the rats show normal brain-bodyweight ratios. This suggests that there is brain sparing during postweaning development in the protein-malnourished rat. This conclusion is also supported by the data reported by Byrne and Smart (1980). They reported that social behavior in the rat is also unaffected by postweaning undernutrition.

The conclusions derived from the studies of human malnutrition that mental retardation occurs as a result of low-protein and poor protein diets consisting mainly of grains and cereals are not supported by the results of this study. The data reported by others suggest that behavioral deficits seen in the human populations may be the result of changes in attentional or emotional factors, rather than deficits in learning abilities.

\section{REFERENCES}

Byrne, E. A., \& Smart, J. L. Delimitation of a sensitive period for the effects of early life undernutrition on social behavior of adult male rats. Physiology \& Behavior, 1980, 23, 131-133.

Cravioto, J., Delicardie, E. R., \& Birch, H. G. Nutrition, growth, and neurointegrative development: An experimental ecological study. Pediatrics, 1966, 38, 319.

Cravioto, J., \& Robles, B. Evolution of adaptive and motor behavior during rehabilitation from kwashiorkor. American Journal of Orthopsychiatry, 1965, 35, 449.

Dent, M. M., \& Caster, W. O. Hyperglycemia and altered performance in rats fed corn grits and chicken skin. Federation Proceedings, 1971, 30, 297A.

Fernstrom, J. D., \& Hirsch, M. J. Brain serotonin synthesis: Reduction in corn-malnourished rats. Journal of Neurochemistry, 1977, 28, 877-879.

Fernstrom, J. D., \& Lytle, L. D. Corn malnutrition, brain serotonin and behavior. Nutrition Reviews, 1976, 34, 257-262.

Forbes, W. B., Tracy, C., Resnick, O., \& Morgane, P. J. Effects of maternal dietary protein restriction on growth of the brain and body in the rat. Brain Research Bulletin, 1977, 2, 131-135.

Gellerman, L. W. Chance orders of alternating stimuli in visual discrimination experiments. Journal of Genetic Psychology, 1933, 42, 207-208.

Kaplan, B. J. Malnutrition and mental deficiency. Psychological Bulletin, 1972, 78, 321-334.

Pan'rhemos, M. D. Biochemical and physiological responses of male, white rats fed common breakfast cereals. Unpublished master's thesis, University of Georgia, 1974.

Segall, P. E., \& Timiras, P. S. Patho-physiologic findings after chronic tryptophan deficiency in rats: A model for delayed growth and aging. Mechanisms of Ageing and Development, 1976, 5, 109-124.

Winick, M. Malnutrition and brain development. London: Oxford University Press, 1976.

Zimmerman, R. B., Geist, C. R., \& Strobel., D. A. Behavioral deficiencies in protein-deprived monkeys. In G. Serban (Ed.), Nutrition and mental functions. New York: Plenum, 1975.

(Received for publication October 1, 1980.) 